\title{
IMMUNOHISTOCHEMICAL EXPRESSION OF C-KIT IN ORAL SQUAMOUS CELL CARCINOMA PATIENTS IN SOUTH INDIAN POPULATIONS
}

\author{
JAYALALITHA SATHIYAMOORTHY ${ }^{1}$, VIDYARANI SHYAMSUNDAR ${ }^{2}$, SUBBIAH SHANMUGAM ${ }^{3}$, \\ JAGADEESAN G MANI ${ }^{3}$, RAJESWARY HARI ${ }^{1 *}$
}

${ }^{1}$ Department of Biotechnology, Dr. M.G.R. Educational and Research Institute, Maduravoyal, Chennai - 600 099, Tamil Nadu, India. ${ }^{2}$ Department of Oral Pathology and Microbiology, Centre of Oral Cancer Prevention and Research, Sree Balaji Dental College and Hospital, Bharath Institute of Higher Education, Pallikaranai, Chennai - 99, Tamil Nadu, India. ${ }^{3}$ Department of Surgical Oncology, Government Royapettah Hospital and Kilpauk Medical College, Chennai, Tamil Nadu, India. Email: rajihar@gmail.com

Received: 21 May 2018, Revised and Accepted: 15 June 2018

ABSTRACT

Objective: The study was designed to evaluate the C-Kit expression and also to assess the relationship with various clinicopathological characteristics in oral squamous cell carcinoma (OSCC) patients.

Methods: A total number of 102 formalin-fixed paraffin-embedded retrospective tissue samples were collected, in which ( $\mathrm{n}=84)$ were histologically confirmed for OSCC, oral epithelial dysplasia (OED) ( $n=9)$, and control group $(n=10)$ and studied immunohistochemically. The baseline characters and the correlation between the protein expression and clinicopathological parameters were analyzed. The survival analysis was performed using Kaplan-Meier Survival Method.

Results: OSCC exhibited C-Kit protein expression positivity of 6\% and OED with $11.11 \%$ with no expression of this protein in control patients. Overall survival analysis showed that patients with negative expression had a better survival than patients with positive expression. However, we found that expression pattern of C-kit did not correlate with various clinicopathological characteristics.

Conclusion: Vast amount of study has to be still performed to under the mechanism of OSCC in C-KIT Expression to enhance the prognosis of OSCC patients in the near future.

Keywords: Oral squamous cell carcinoma, Oral epithelial dysplasia, Immunohistochemistry, C-KIT.

(c) 2018 The Authors. Published by Innovare Academic Sciences Pvt Ltd. This is an open access article under the CC BY license (http://creativecommons. org/licenses/by/4. 0/) DOI: http://dx.doi.org/10.22159/ajpcr.2018.v11i10.27443

\section{INTRODUCTION}

Head and neck cancer is one of the most common cancers which ranks sixth among all other cancers [1]. Oral cancer is considered as the major problem in the developing countries and as well in other developed countries. However, approximately 2,74,300 cases are newly diagnosed oral cancer every year in which almost two-thirds of the populations are diagnosed in the developing countries [2]. In India, oral squamous cell carcinoma (OSCC) ranks third among the frequent cancers with an annual incidence of 52,000 patients and a mortality of $77 \%$ in developing nations. However, it is also found that OSCC is considered as most commonly occurring malignant disorder among the Southeast Asian populations [3]. In spite of the drastic improvement in therapeutic treatment, the 5-year survival rate is reported to be poor comprising of about $50-60 \%$, specifically due to the fact that most of patients are resistant to chemotherapy [4-6]. In India, oral cancer is most commonly found among men rather than women populations. Tobacco and alcohol consumption is considered as a major risk factor for the cause of OSCC. However, socioeconomic status people show the higher incidence rate for causing oral cancer among which low socioeconomic status people are prone to higher risk of developing oral cancer [7].

CD117 is encoded by the proto-oncogene C-Kit, which is a transmembrane protein belonging to the Type III subfamily of the receptor tyrosine kinases that bind to the stem cell factor and also an most important regulator in the growth of the cells $[8,9]$. However, it is also known that CD117 plays a very important mechanism in melanogenesis, hematopoiesis, spermatogenesis, and carcinogenesis as well. In addition, CD117 has been expressed in various normal cells types such as mast cells, germ cells, melanocytes, and breast epithelial cells [10]. CD117 has been studied in different types of tumors such as breast cancer, non-small cell lung cancer, esophageal, hepatocellular carcinoma, respectively [1014]. Despite there are various studies performed in other cancers, it was found that CD117 plays an inadequate role in the oral cancer. Thus, the aim of our study was to investigate the immunohistochemical expression of CD117 in OSCC among the South Indian populations.

\section{METHODS}

\section{Collection of samples}

In the present investigation, the total number of samples included for the expression of C-Kit was 102 which includes both the males $(n=73)$ and females $(\mathrm{n}=29)$. Retrospective formalin-fixed paraffin-embedded tissue (FFPE) samples were obtained and were clinically grouped as OSCC ( $\mathrm{n}=84)$, oral epithelial dysplasia (OED, $\mathrm{n}=9$ ), and control samples $(n=9)$. Clinical data were obtained from the patients for the study purpose. The baseline characteristics of the study population were generated. The study was approved by the Institution Ethics Committee of (a) A.C.S Medical College, Chennai, (b) Sree Balaji Dental College and Hospital, and (c) Government Tertiary Care Centre, Chennai.

Immunohistochemical analysis

Retrospective FFPE samples were stained with hematoxylin-eosin. Stained slides were subjected to histopathological examinations and confirmed with the help of experienced oral pathologist from Private Dental College, Chennai, for the presence of tumor cells. Immunohistochemistry was performed with 3-5 $\mu \mathrm{m}$ sections of FFPE tissues. The sections were placed over 3-Aminopropyltriethoxysilane 
coated slides (Sigma-Aldrich, USA) and dewaxed through three changes of xylene and hydrated through various descending grades $(100 \%$ and $70 \%)$ of alcohol, respectively. The slides were gently washed with distilled water twice for $5 \mathrm{~min}$ each and were immersed in freshly prepared $3 \%$ hydrogen peroxide solution for 20 min to block endogenous peroxidase activity and again washed with distilled water twice for $5 \mathrm{~min}$. Antigen retrieval was performed with 1M Tris-EDTA Buffer ( $\mathrm{pH}-9)$ in a pressure cooker and the slides were washed twice again with distilled water. Sections were preincubated with $2 \%$ bovine serum albumin (Sigma, US) for 30-40 min and then incubated in a moist chamber stored at $4^{\circ} \mathrm{C} .10-20 \mu \mathrm{l}$ of C-KIT primary antibody (PathnSitu, USA) was added to each section, and the samples were incubated in $100 \%$ moisture chamber and stored at $4^{\circ} \mathrm{C}$ for overnight. In the $2^{\text {nd }}$ day procedure, the slides were washed twice with freshly prepared $\times 1$ phosphate buffered saline (PBS) ( $\mathrm{pH}-7.6)$ solution for 5 min each. The slides were then incubated with $10 \mu \mathrm{l}$ of secondary antibody and kept in a moist chamber for $45 \mathrm{~min}$ and once again washed twice with freshly prepared $\times 1$ PBS solution. For visualization, the sections were incubated with $5 \mu \mathrm{l}$ of DAB chromagen for $5 \mathrm{~min}$ and washed with distilled water twice and counterstained using hematoxylin stain for $45 \mathrm{~s}$. The slides were dehydrated with different grades of alcohol and dipped in xylene for $5 \mathrm{~min}$ and mounted with DPX. The slides were directly captured using ProgRes Capture Pro 2.8.8 software (JENOPTIK optical systems) at $\times 4$ objective magnification.

\section{IHC scoring}

The percentage of positive cells was estimated, and the staining intensity was recorded. The percentage of positively stained cells is as follows: $0 \%=0,1-5 \%=1,6-10 \%=2$, and $>10 \%=3$. All the cells were counted in 10 random areas and presented as the percentage of positive cells. The staining intensity was recorded as negative, mild, moderate, and strong. A final expression score was calculated by multiplying labeling index score with intensity score, based on which further statistical analyses were performed as, the negative (score 0) were compared with the positive ones (scores 1-3). All the relevant clinical data, histopathological parameters, and immunohistochemical data were tabulated and subjected to appropriate statistical analysis.

\section{Statistical analysis}

All statistical analysis was performed with the help of IBM Statistical Package for the Social Sciences version 20.0 (Chicago, IL, USA). Numerical data were expressed as the mean \pm standard deviation. The comparisons of numerical data were performed by independent sample t-test, and association between factors, including clinicopathological variables, were assessed with the help of Chi-square or Fisher test. Hazard ratios (HRs) were assessed using Cox univariate analysis, and multivariate logistic regression was used to obtain odds ratio (OR) and confidence intervals (CI: 95\%.). Overall survival analysis was performed using Kaplan-Meier method, and the statistical significance was analyzed with log-rank test. HRs were assessed using Cox univariate analysis, and multivariate survival analysis was carried out using Cox proportional hazards model. $\mathrm{p}<0.05$ was considered to be statistically significant.

\section{RESULTS}

Patient's study characteristics for proto-oncogene C-kit expression A total number of 102 samples were examined for the expression of C-kit which included both the males $(n=73)$ and females $(n=29)$. The samples were clinically grouped as OSCC $(n=84)$, OED $(n=9)$, and control group $(\mathrm{n}=9)$. The mean age in the case of OSCC was $53.72 \pm 13.16$ in which the age of the patients ranged between 27 and 86 years, and the mean age of $50.66 \pm 10.59$ was observed for OED with the age group ranging between 29 and 73 years. The control group comprising of the age group of 29-73 years showed a mean age group of $56.11 \pm 13.78$. The baseline of the patient's characteristics such as gender, chewing or smoking tobacco, and alcohol consumption was studied among the different study population and is tabulated in Table 1.

\section{Immunohistochemical expression for C-kit}

In the present investigation, based on the IHC scoring, only $6.0 \%$ of the patients (5 of 84) in the OSCC group showed a positive expression of the $\mathrm{C}$-kit protein expression, whereas in the control group, it was $100 \%$ negative, and in OED group, though $11.11 \%$ (1 of 9) positive expression is seen (Fig. 1). Hence, we analyzed the correlation between the expression pattern of this protein and the clinicopathological conditions of the OSCC patient group and presented the findings. In the present investigation, we found a significant association of the expression of this protein with that of age $(\mathrm{p}=0.025)$, whereas less significant association is observed as far as other pathological parameters such as cancer location $(\mathrm{p}=0.138)$, smoking $(\mathrm{p}=1.000)$, alcohol $(\mathrm{p}=0.645)$, chewers with smokers $(p=0.672)$, chewers with alcohol $(p=0.363)$, smoking with alcohol $(\mathrm{p}=1.000)$, among all habits $(\mathrm{p}=0.644)$, gender $(p=0.621)$, chewing $(p=0.478)$, emphasis status $(p=0.164)$, pattern of invasion $(\mathrm{p}=0.957)$, lymphovascular invasion $(\mathrm{p}=1.000)$, muscle involvement $(\mathrm{p}=0.062)$, progression stage $(\mathrm{p}=0.647)$, local recurrence $(p=0.192)$, locoregional recurrence $(p=1.000)$, Bryne grade $(p=0.921)$, depth of invasion ( $\mathrm{p}=0.571)$, treatment $(\mathrm{p}=0.069)$, and pathological identification $(\mathrm{p}=1.000)$ are concerned. The clinicopathological characteristics for C-Kit expression are summarized in Table 2.

\section{Survival Analysis for C-kit}

The survival analysis was performed using Kaplan-Meier Survival Method to find the survival status of the patients in terms of their positive and negative expression of this protein in OSCC groups. As far as $\mathrm{C}$-Kit protein expression is concerned, negatively expressed patients showed better survival rate than positive expressed patients with $95 \%$ CI. Negatively expressed patients showed a survival of 27-34 months with the mean of $31 \pm 1.8$, and it was 24-32 months with the mean of $28 \pm 2.1$ in the case of positively expressed patients. The overall survival analysis using Kaplan-Meier survival with log-rank showed less significant association in C-Kit expression with that of survival $(p=0.590$ ) (Fig. 2). Using logistic regression model generated for protooncogene C-kit, only age showed as influencing factor $(\mathrm{OR}=1.108$,

Table 1: Baseline clinical characteristics of recruited groups for C-Kit expression

\begin{tabular}{|c|c|c|c|}
\hline Parameters & OSCC (\%) n (\%) & OED (\%) & Control (\%) \\
\hline Number of patients & $(n=84)$ & $(n=9)$ & $(n=9)$ \\
\hline \multicolumn{4}{|l|}{ Gender } \\
\hline Male & $60(71.4)$ & 7 (77.8) & $5(55.6)$ \\
\hline Female & $24(28.6)$ & $2(22.2)$ & $4(44.4)$ \\
\hline \multicolumn{4}{|l|}{ Chewers } \\
\hline Yes & 74 (88.1) & $9(100)$ & $0(0.0)$ \\
\hline No & $10(11.9)$ & $0(0.0)$ & $9(100)$ \\
\hline \multicolumn{4}{|l|}{ Alcohol } \\
\hline Yes & 49 (58.3) & $3(33.3)$ & $0(0.0)$ \\
\hline No & 35 (41.7) & $6(66.7)$ & $9(100)$ \\
\hline \multicolumn{4}{|l|}{ Smokers } \\
\hline Yes & $52(61.9)$ & $6(66.7)$ & $0(0.0)$ \\
\hline No & $32(38.1)$ & $3(33.3)$ & $9(100)$ \\
\hline \multicolumn{4}{|l|}{$\begin{array}{l}\text { Chewing with } \\
\text { smokers }\end{array}$} \\
\hline Yes & $43(51.2)$ & $6(66.7)$ & $0(0.0)$ \\
\hline No & $41(48.8)$ & $3(33.3)$ & $9(100)$ \\
\hline \multicolumn{4}{|l|}{$\begin{array}{l}\text { Chewing with } \\
\text { alcohol }\end{array}$} \\
\hline Yes & $40(47.6)$ & $3(33.3)$ & $0(0.0)$ \\
\hline No & $44(52.4)$ & $6(66.7)$ & $9(100)$ \\
\hline \multicolumn{4}{|l|}{$\begin{array}{l}\text { Smoking with } \\
\text { alcohol }\end{array}$} \\
\hline Yes & $42(50)$ & $3(3.3)$ & $0(0.0)$ \\
\hline & $42(50)$ & $6(66.7)$ & $9(100)$ \\
\hline \multicolumn{4}{|l|}{ All habits } \\
\hline Yes & $33(39.3)$ & $3(33.3)$ & $0(0.0)$ \\
\hline No & $51(60.7)$ & $6(66.7)$ & $9(100)$ \\
\hline
\end{tabular}




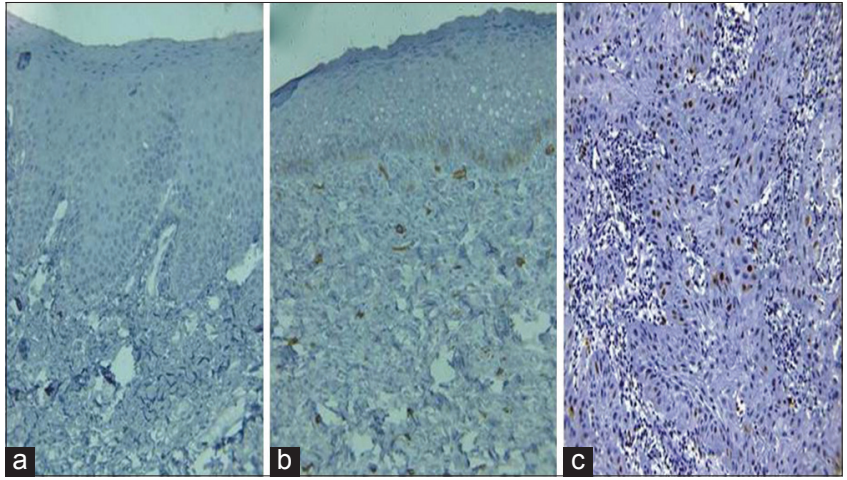

Fig. 1: IHC Expression of C-Kit (a) Normal Mucosa, $\times 20$, (b) mild Dysplasia, $\times 20$, (c) nuclear staining in oral squamous cell carcinoma patients, $\times 20$

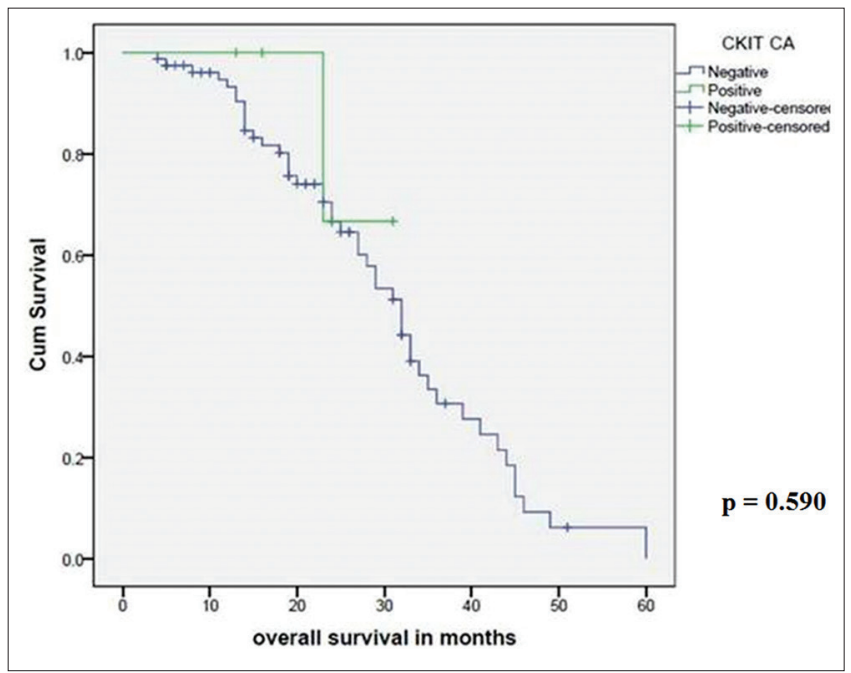

Fig. 2: Kaplan-Meier Survival analysis for C-Kit expression

95\% CI: $1.005-1.222, \mathrm{p}=0.040$ ). In multivariate Cox proportional hazards, regression analysis that adjusted for the effects showed that pathological identification (HR=0.345, 95\%CI: 0.176-0.676, $\mathrm{p}=0.002$ ) and progression stage (HR=0.356, 95\%CI: $0.191-0.666, \mathrm{p}=0.001$ ) were considered as the risk factor for overall survival analysis.

\section{DISCUSSION}

CD117 is also known as c-Kit, proto-oncogene, or tyrosine-protein kinase kit which is a receptor in tyrosine kinase protein that is present in humans is encoded by KIT gene which plays an important role in cell survival, cell proliferation and cell differentiation. The overexpression of this protein can lead to cancer [15]. Several studies conducted on various types of cancers such as gastrointestinal cancers, renal cancers, small cell lung cancer, pancreatic cancers, and breast cancers have reported the overexpression of CD117. A study conducted by Miettinen et al. 2000 [16] showed 95\% positive immune stained of C-Kit protein in gastrointestinal tumor and suggested the use of this protein as a biomarker for the diagnosis of GIST. Similarly, Beltran et al. 2006 [17] also showed a $100 \%$ positive expression in adenoid cystic carcinoma and Stemberger-Papic et al. 2014 [18] showed that C-Kit expression was seen in $81 \%$ of ovarian tumor samples indicating the prevalence of higher expressions in secretory organs.

There are certain types of cancers such as invasive ductal carcinoma breast [19] and thymic epithelial carcinoma [20], where only $46 \%$ CKITpositive expression was observed. At the same time, there are certain types of cancers, and Medinger et al. 2010 [21] have observed lower expression of the C-kit protein. Medinger et al. 2010 [21] have observed
Table 2: Immunohistochemical expression of Clinicopathological characteristics for OSCC patients

\begin{tabular}{|c|c|c|}
\hline Parameters & C-Kit positive & p value \\
\hline Age & 5 & 0.025 \\
\hline \multicolumn{3}{|l|}{ Gender } \\
\hline Male & $3(60)$ & \multirow[t]{2}{*}{0.621} \\
\hline Female & $2(40)$ & \\
\hline \multicolumn{3}{|l|}{ Cancer location } \\
\hline Buccal mucosa & $2(40)$ & \multirow[t]{2}{*}{0.138} \\
\hline Tongue & $3(60)$ & \\
\hline \multicolumn{3}{|l|}{ Chewing } \\
\hline Yes & $4(80)$ & \multirow[t]{2}{*}{0.478} \\
\hline No & $1(20)$ & \\
\hline \multicolumn{3}{|l|}{ Smoking } \\
\hline Yes & $3(60)$ & \multirow[t]{2}{*}{1.000} \\
\hline No & $2(40)$ & \\
\hline \multicolumn{3}{|l|}{ Alcohol } \\
\hline Yes & $2(40)$ & \multirow[t]{2}{*}{0.645} \\
\hline No & $3(60)$ & \\
\hline \multicolumn{3}{|l|}{ Chewing with smoking } \\
\hline Yes & $2(40)$ & \multirow[t]{2}{*}{0.672} \\
\hline No & $3(60)$ & \\
\hline \multicolumn{3}{|l|}{ Chewing with alcohol } \\
\hline Yes & $1(20)$ & \multirow[t]{2}{*}{0.363} \\
\hline No & $4(80)$ & \\
\hline \multicolumn{3}{|l|}{ Smoking with alcohol } \\
\hline Yes & $2(40)$ & \multirow[t]{2}{*}{1.000} \\
\hline No & $3(60)$ & \\
\hline All Habits & & \\
\hline Yes & $1(20)$ & 0.644 \\
\hline No & $4(80)$ & \\
\hline T-stage & & \\
\hline Yes & $1(20)$ & 0.647 \\
\hline No & $4(80)$ & \\
\hline Local recurrence & & \\
\hline Yes & $2(40)$ & 0.192 \\
\hline No & $3(60)$ & \\
\hline Local regional recurrence & & \\
\hline Yes & $0(0)$ & 1.000 \\
\hline No & $5(100)$ & \\
\hline Treatment & & \\
\hline Surgery alone & $0(0)$ & 0.069 \\
\hline $\begin{array}{l}\text { Surgery with prechemotherapy } \\
\text { and preradiotherapy }\end{array}$ & $1(20)$ & \\
\hline $\begin{array}{l}\text { Surgery with postchemotherapy } \\
\text { and postradiotherapy }\end{array}$ & $2(40)$ & \\
\hline Palliative therapy & $2(40)$ & \\
\hline Emphasis status & & \\
\hline Alive & $1(20)$ & 0.164 \\
\hline Dead & $4(80)$ & \\
\hline Pathological identification & & \\
\hline WDSCC & $4(80)$ & 1.000 \\
\hline MDSCC & $1(20)$ & \\
\hline Lymphovascular invasion & & \\
\hline Yes & $2(40)$ & 1.000 \\
\hline No & $3(60)$ & \\
\hline Muscle involvement & & \\
\hline Yes & $5(100)$ & 0.062 \\
\hline No & $0(0)$ & \\
\hline Not seen & $0(0)$ & \\
\hline Bryne grade & & \\
\hline Grade 1 & $1(20)$ & 0.921 \\
\hline Grade 2 & $3(60)$ & \\
\hline Grade 3 & $1(20)$ & \\
\hline Depth of invasion & & \\
\hline Grade 1 & $0(0)$ & 0.571 \\
\hline Grade 2 & $4(80)$ & \\
\hline Grade 3 & $1(20)$ & \\
\hline
\end{tabular}

OSCC: Oral squamous cell carcinoma

lower expression of the C-kit among which $17 \%$ were observed in colorectal cancers, $35 \%$ in sarcomas, $36 \%$ in renal cell carcinoma 
patients, $17 \%$ in ovarian cancers, $21 \%$ breast cancer patients and $17 \%$ of the hepatocellular carcinoma patients. However, the expression pattern was also found to be lower in most of the carcinoma-like pleomorphic carcinoma (0.6\%), squamous cell carcinoma (3.4\%), large cell carcinomas (5.5\%), adenocarcinomas (23.4\%), and adenosquamous carcinomas (66.8\%) as indicated in the study by Kriegsmann 2015 [22]. In our study performed with CD117, in the oral cancer patients, we found only $6.0 \%$ expression in OSCC, $11.11 \%$ in OED cases, and $100 \%$ negative expression in control cases. However, to the best of our knowledge, the current study was performed to evaluate the expression of C-Kit in OSCC patients belonging to the South Indian population. From our study, we could not find any contributing clinicopathological factors for OSCC patients in C-Kit protein expression due to the low sample size.

\section{CONCLUSION}

The current Immunohistochemical study was performed to identify the expression of C-Kit in OSCC, OED, and normal oral mucosa. However, it is found that C-Kit expression was not found to serve as a good prognostic factor in our study. Hence, further studies have to be performed on large-scale sample size with the help of prospective samples and as well as with various advanced molecular techniques which can also further help us to identify whether C-Kit can play as an important diagnostic and as well as prognostic tool in near future which can also pave a way in the advancement of targeted therapy in the near future for OSCC patients.

\section{ACKNOWLEDGMENTS}

The authors would like to thank Dr. M.G.R Educational and Research Institute, Maduravoyal, Chennai, and Centre of Oral Cancer Prevention and Research, Sree Balaji Dental College and Hospital, Pallikaranai, Chennai, for providing necessary facilities to carry out this work.

\section{AUTHOR'S CONTRIBUTION}

Jayalalitha Sathiyamoorthy and Vidyarani Shyamsundar contributed for acquisition of data and interpretation of data, Subbiah Shanmugam helped for providing clinical samples. Jagadeesan.G.Mani contributed for the acquisition of clinical samples and clinical datas, and Rajeswary Hari contributed to conception and as well design of the study and revising the article for intellectual content. All authors approved the final version of the manuscript for publication.

\section{REFERENCES}

1. Hasan S, Elongovan S. Conventional and advanced diagnostic aids in oral cancer screening - The journey so far. Int J Pharm Pharm Sci 2014;7:29-33.

2. Petersen PE. Strengthening the prevention of oral cancer: The WHO perspective. Community Dent Oral Epidemiol 2005;33:397-9.

3. Manasaveena V, Akula KK, Sangram V. A comparative evaluation of enzymatic antioxidant levels in pre and post therapy patients with oral cancer. Int J Pharm Pharm Sci 2014;6:52-56.

4. Scully C, Bagan JV. Oral squamous cell carcinoma: Overview of current understanding of aetiopathogenesis and clinical implications. Oral Diseases 2009;15:388-99.

5. Kademani D. Oral cancer. Mayo Clin Proc 2007;82:878-87.

6. Parkin DM, Bray F, Ferlay J, Pisani P. Global cancer statistics, 2002. CA Cancer J Clin 2005;55:74-108.

7. Conway DI, Petticrew M, Marlborough H, Berthiller J, Hashibe M, Macpherson LM, et al. Socioeconomic inequalities and oral cancer risk: A systematic review and meta-analysis of case-control studies. Int J Cancer 2008;122:2811-9.

8. Chabot B, Stephenson DA, Chapman VM, Besmer P, Bernstein A. The proto-oncogene c-kit encoding a transmembrane tyrosine kinase receptor maps to the mouse W locus. Nature 1988;335:88-9.

9. Butnor KJ, Burchette JL, Sporn TA, Hammar SP, Roggli VL. The spectrum of kit (CD117) immunoreactivity in lung and pleural tumors: A study of 96 cases using a single-source antibody with a review of the literature. Arch Pathol Lab Med 2004;128:538-43.

10. Miettinen M, Lasota J. KIT (CD117): A review on expression in normal and neoplastic tissues, and mutations and their clinicopathologic correlation. Appl Immunohistochem Mol Morphol 2005;13:205-20.

11. Becker G, Schmitt-Graeff A, Ertelt V, Blum HE, Allgaier HP. CD117 (c-kit) expression in human hepatocellular carcinoma. Clin Oncol 2007;19:204-8.

12. Shams TM, Shams ME. Overexpression of c-KIT (CD117) in triplenegative breast cancer. Egypt J Pathol 2011;31:113-7.

13. Donnenberg $\mathrm{AD}$, Zimmerlin L, Landreneau RJ, Luketich JD, Donnenberg VS. KIT (CD117) expression in a subset of non-small cell lung carcinoma (NSCLC) patients. PLoS One 2012;7:e52885.

14. Fan H, Yuan Y, Wang J, Zhou F, Zhang M, Giercksky KE, et al. CD117 expression in operable oesophageal squamous cell carcinomas predicts worse clinical outcome. Histopathology 2013;62:1028-37.

15. Andre C, Hampe A, Lachaume P, Martin E, Wang XP, Manus V, et al. 'Sequence analysis of two genomic regions containing the KIT and the FMS receptor tyrosine kinase genes'. Genomics 1997;39:216-22.

16. Miettinen M, Sobin LH, Sarlomo-Rikala M. Immunohistochemical spectrum of GISTs at different sites and their differential diagnosis with a reference to CD117 (KIT). Modern Pathol 2000;13:1134-42.

17. Beltran D, Faquin WC, Gallagher G, August M. Selective Immunohistochemical comparison of polymorphous low-grade adenocarcinoma and adenoid cystic carcinoma. J Oral Maxillofac Surg 2006;64:415-23

18. Stemberger-Papic S, Vrdoljak-Mozetic D, Versa Ostojic D, RubesaMihaljevic R, Kristofic I, Brncic-Fischer A, et al. Expression of CD133 and CD117 in 64 serous ovarian cancer cases. Coll Antropol 2015;39:745-53.

19. Shomaf M, Yousef AM, Masad J, Sahawneh M, Halawa A. C-kit (CD117) expression is not valuable to predict prognosis in invasive ductal carcinoma of breast. J Interdisciplinary Histopathol 2016;4:63-6.

20. Petrini I, Zucali PA, Lee HS, Pineda MA, Meltzer PS, Walter-Rodriguez B, et al. Expression and mutational status of c-kit in thymic epithelial tumors. J Thoracic Oncol 2010;5:1447-53.

21. Medinger M, Kleinschmidt M, Mross K, Wehmeyer B, Unger C, Schaefer, HE, et al. C-kit (CD117) expression in human tumors and its prognostic value: An immunohistochemical analysis. Pathol Oncol Res 2010;16:295-301.

22. Kriegsmann M, Muley $\mathrm{T}$, Harms A, Tavernar L, Goldmann T, Dienemann H. Differential diagnostic value of CD5 and CD117 expression in thoracic tumors: A large scale study of 1465 non-small cell lung cancer cases. Diagnostic Pathol 2005;10:1-6. 